
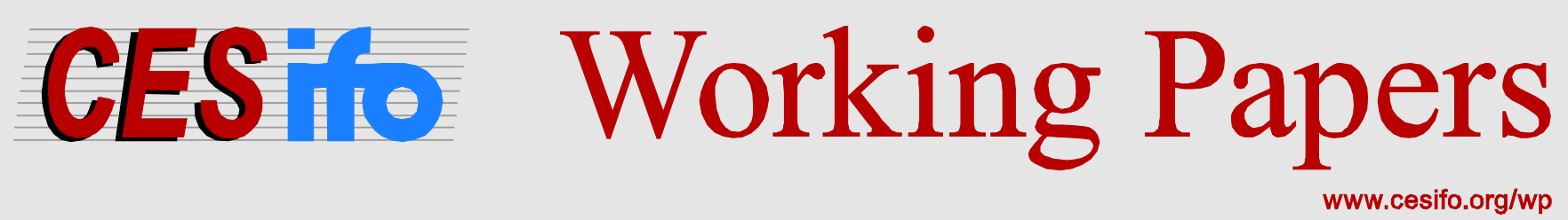

\title{
Oil Project Selection by Metrics
}

\author{
Magne Emhjellen \\ Petter Osmundsen
}

CESIFO WORKING PAPER NO. 5898

CATEGORY 13: BEHAVIOURAL ECONOMICS

MAY 2016

An electronic version of the paper may be downloaded

- from the SSRN website:

- from the RePEc website:

- from the CESifo website: WWW.SSRN.com

www.RePEc.org

www.CESifo-group.org/wp 


\title{
Oil Project Selection by Metrics
}

\begin{abstract}
The recent fall in oil prices has led to extensive capital rationing, and thereby given rise to a renewed focus on parameters for project selection which supplement net present value. While the financial crisis was creating capital constraints, the oil industry seemed to be paying great attention to the net present value index. The metric most often referred to at present, given the prevailing uncertainty over the direction of future oil prices, seems to be the breakeven price of a project. Management and professionals in the oil and gas sector, as well as industry analysts, appear to be very concerned about which criteria in addition to net present value other companies are applying in their decision-making. Our findings indicate that they can be more relaxed here, since the various supplementary criteria provide very similar rankings. We examine the different investment metrics of a portfolio of oil projects. The analysis of project metrics shows that the overall grouping of projects is the same with the three supplementary metrics. The concentration by the companies on robustness related to oil prices means that particular attention is paid to the breakeven price and cost optimisation. Projects which are optimised and sanctioned may have a very high return with the realisation of an expected price scenario. We introduce a new metric, referred to as the complete net present value index, which improves the traditional net present value index by including operating expenditure and by treating taxes in a consistent manner.
\end{abstract}

JEL-Codes: Q400, G120, G310.

Keywords: project metrics, project valuation, oil projects.

\author{
Magne Emhjellen \\ Petoro AS / Norway \\ magne.emhjellen@petoro.no
}

Petter Osmundsen

University of Stavanger / Norway

Petter.Osmundsen@uis.no 


\section{Introduction}

The fall in oil prices has once again imposed capital constraints, with cancellations and delays for project decisions in the oil industry as the result. In Norway, for example, Statoil as operator for the Snorre Extension and Johan Castberg oil projects has further postponed the decision to go ahead on the grounds that it needs to undertake additional optimisation and evaluation. Other oil companies are also delaying and cancelling oil projects. This may be the correct approach, for the simple reason that these developments are not profitable with a new view on expected future oil prices. It may also be right because future price uncertainty has increased, enhancing the option value of waiting. On the other hand, the projects may all have positive NPVs but capital rationing has been introduced. See Osmundsen et al (2006).

In economic theory, when an investment regime with constraints is introduced, the correct solution is to apply a portfolio model in order to choose the combination of projects in the opportunity set with the highest overall net present value. This is often simplified in order to achieve decentralised evaluation in organisations which make investment decisions on a daily basis, as well as in different countries with varying fiscal regimes, by looking at key metrics such as the internal rate of return, the net present value index and the breakeven price of the projects. See Emhjellen et al (2006).

The reasoning behind this is that formal optimisation of the project portfolio can only be undertaken at the highest corporate level, and that the organisation thereby needs simplified metrics for testing project profitability. These also function as financial targets for the organisation and create discipline, with a reduced number of projects being presented to management for decision.

We evaluate the three metrics most often used for the simplified selection of oil projects. We also introduce a new metric which we believe makes more economic sense in that it includes all costs, not only investment, and also reflects time value and risk. We examine the results and conclude that, for these four metrics, the most profitable projects are all in the highest ranked group and their individual ranking is also the same. Only when the capital rationing constraint is relaxed and the less profitable developments are included will the project selection metrics give somewhat different results. 
In section 2, we describe the four different metrics we use to evaluate the projects in terms of ranking. Section 3 examines the portfolio ranking of model oil and gas projects on the basis of these metrics. We conclude in section 4 .

\section{The four metrics}

For a discussion of current issues pertaining to petroleum investment projects, in absence of capital constraints, see Osmundsen et al. (2015). The investment decision when some constraint exists becomes rather more complicated than accepting all projects with an NPV greater than zero (Ingersoll and Ross, 1992). Myers, 1974, showed that the weighted average cost of capital is not correct when capital constraints apply and that a solution must be found at the corporate portfolio level.

Project metrics are often calculated to simplify this analysis below the corporate level so that individual divisions can promote their projects to central management with a degree of certainty.

The first metric is the internal rate of return (IRR), which is described in many finance textbooks (see, eg, Brealey and Myers, 2011; Copeland and Weston, 2005). It is defined as the rate of return which gives an NPV of zero:

$$
N P V=\sum_{t=0}^{T} \frac{X_{t}}{(1+I R R)^{t}}=0,
$$

where $\mathrm{Xt}$ is the expected net cash flow after tax in period $\mathrm{t}^{1}$

The second metric is the net present value index (NPVI). It is defined as the after-tax NPV of the project $^{2}$ divided by the before-tax NPV of the investment (Kind, Tveteras and Osmundsen, 2005)..$^{3}$

$N P V I=$ NPVprojectaftertax / NPVCapexbeforetax

\footnotetext{
${ }^{1}$ This uses the company's required rate of return, which often is based on the capital asset pricing model (CAPM - Sharpe, 1964; Lintner, 1965; Mossin, 1966) with an added term.

${ }^{2}$ For a good overview of principles and practicalities of determining the discount rate, see Gjesdal and Johnsen (1999).

${ }^{3}$ Companies apply traditional NPV values, i.e., all cash flow components are discounted by the same discount rate. For a discussion of differentiated discount rates applied to partial cash flows, see Osmundsen et al. (2015).
} 
The NPVI seems to be a popular metric in the oil industry at times of capital rationing, but appears to have a serious flaw in that an after-tax NPV is divided by a before-tax Capex. This seems to be inconsistent. One argument defending this practice is that oil companies are often short not on capital but on critical expertise and personnel, and that before-tax Capex is a better proxy for the number of critical personnel needed. This may have been a reasonable description of the international oil companies in the recent boom years. At present, however, with oil prices down more than 60 per cent, capital is the scarcest input factor. If the tax system bears a large fraction of the investment, this should also be accounted for. In other words, we will argue that after-tax Capex is a more suitable denominator in equation (2.2). Nor is operating cost evaluated in the standard NPVI, which creates incentives to shift categorisation from investment to operating cost, or even distortions in the form of a shift towards less capital intensive development concepts.

Given our objection to the traditional NPVI, we introduce an improved metric which we refer to as the complete net present value index (CNPVI):

$$
C N P V I=N P \text { Vaftertax } / \sum_{t=0}^{T} \frac{C_{t}(1-t)}{(1+r)^{t}}
$$

This metric is more correct in terms of economics where the NPV criterion is concerned, since all costs, both Capex and Opex, are included and we use after-tax values in both numerator and denominator.

The fourth metric is the breakeven price (BEP) of the project (Jovanovic, 1999). It is often used by the oil industry in times like the present, when oil prices are volatile. ${ }^{4}$ This is a variant of (2.1) in that the variable to be estimated (BEP) is in the numerator:

$$
N P V=\sum_{t=0}^{T} \frac{\left(x_{t} P-C_{t}\right)(1-s)}{(1+r)^{t}}=0
$$

\footnotetext{
${ }^{4}$ The financial press frequently reports on breakeven prices in different extraction regions, and currently much attention is on the breakeven price of US tight oil; see e.g., http://uk.businessinsider.com/cash-cost-breakevenoil-prices-2015-12?r=US\&IR=T. In the academic literature, we do not find much on BEP as a straight forward decision criterion. Instead, the literature addresses evaluation of investment projects involving both uncertainty and flexibility (see e.g., Bjerksund and Ekern, 1990). The focus here is on an investment opportunity where the deferrable investment decision may be made contingent on future emerging information on the risky output price. Decision criteria are in the form of adjusted breakeven prices.
} 
In equation (2.4), $x_{t}$ is production at time $\mathrm{t}, C_{t}$ is the cost at time $\mathrm{t}$, and $\mathrm{P}$ is the constant price which gives an NPV equal to zero after tax, i.e., the BEP. The tax rate is $s$. The solution is obtained by iteration.

An example of applying BEP as investment decision criteria is provided by Statoil. The oil company presented a breakeven price requirement of USD 50 per barrel for all projects on its Capital market Day in June 2015. This was clearly a capital rationing mechanism, as they at the same time operated with an expected oil price of USD 80 per barrel (Norwegian Business Daily (DN), August 24, 2015).

\section{Portfolio analysis}

The oil and gas projects are based on data from Rystad Energy. We assume a four per cent annual cost increase from 2012 and an exchange rate of NOK 7 to the USD. Our approach is to treat these recent oil developments as future projects in order to evaluate the project ranking yielded by different metrics. As such, the project values have no connection with their actual NPVs at the time when the oil companies submitted their required plan for development and operation (PDO) to the Norwegian Ministry of Petroleum and Energy. We have made simplifying assumptions for the scheduling of investment figures by compiling Capex profiles of 30, 40 and 30 per cent in the years before start up, and assume that these are future projects for decision with a possible start up in 2016 following valuation and decision in 2015. For the sake of simplification, we also assume that resources in the oil and gas projects are produced evenly over 10 years where they exceed 50 million barrels of oil equivalent and over four years for resources smaller than 50 million barrels. When calculating the net present value of the projects, we use a real required rate of return of seven per cent. A price expectation by the oil companies of USD 80 in 2015 and an operating cost per barrel of USD 20 are assumed. 
Table 3.1 Project investment and volumes

\begin{tabular}{lcc} 
& Mill. 2015 USD & Mill Boe \\
\cline { 2 - 3 } Valemon & 4319 & 211 \\
Gudrun & 3049 & 123 \\
Ekofisk South & 4377 & 189 \\
Eldfisk II & 6089 & 252 \\
Yme & 2268 & 75 \\
Martin Linge & 4120 & 195 \\
Edvard Grieg & 3890 & 182 \\
Skarv & 7579 & 437 \\
Knarr & 1852 & 58 \\
Goliat & 5969 & 242 \\
Gjøa & 5374 & 354 \\
Vega + Vega sør & 1658 & 146 \\
Stjerne & 800 & 45 \\
Vigdis Northeast & 718 & 33 \\
Skuld & 1631 & 91 \\
Visund South & 837 & 98 \\
Njord NW Flank & 289 & 19 \\
Visund North & 837 & 29 \\
Vilje South & 177 & 8 \\
Hyme & 768 & 26 \\
Trym & 502 & 36 \\
Oselvar & 823 & 53 \\
Alta & 222 & 11 \\
Marulk & 719 & 74 \\
Gaupe & 382 & 31 \\
Jette & 467 & 13 \\
Brynhild & 736 & 20
\end{tabular}

Table 1: 27 PDOs in Norway where investment figures have been inflated by four per cent per annum from 2012 and converted to USD at an exchange rate of NOK 7.

The results of using the data and assumptions to calculate the NPV and the metrics are presented in Table 3.2 
Table 3.2 NPV and metrics

\begin{tabular}{|c|c|c|c|c|c|c|}
\hline & NPV after tax & $\underline{\text { IRR }}$ & NPV index & $\begin{array}{c}\text { Breakeven } \\
\text { USD/bbl }\end{array}$ & $\begin{array}{c}\text { NPV/ } \\
\text { NPV Cost }\end{array}$ & Mill. 2015 USD \\
\hline Valemon & 766 & $20 \%$ & 0.18 & 49 & 0.56 & 4319 \\
\hline Gudrun & 344 & $16 \%$ & 0.11 & 55 & 0.38 & 3049 \\
\hline Ekofisk South & 588 & $18 \%$ & 0.13 & 53 & 0.45 & 4377 \\
\hline Eldfisk II & 735 & $17 \%$ & 0.12 & 54 & 0.41 & 6089 \\
\hline Yme & 131 & $12 \%$ & 0.06 & 62 & 0.21 & 2268 \\
\hline Martin Linge & 683 & $20 \%$ & 0.17 & 50 & 0.53 & 4120 \\
\hline Edvard Grieg & 629 & $19 \%$ & 0.16 & 50 & 0.52 & 3890 \\
\hline Skarv & 1849 & $24 \%$ & 0.24 & 45 & 0.72 & 7579 \\
\hline Knarr & 83 & $11 \%$ & 0.04 & 65 & 0.16 & 1852 \\
\hline Goliat & 683 & $16 \%$ & 0.11 & 55 & 0.39 & 5969 \\
\hline Gjøa & 1645 & $28 \%$ & 0.31 & 42 & 0.85 & 5374 \\
\hline Vega + Vega sør & 786 & $36 \%$ & 0.47 & 37 & 1.14 & 1658 \\
\hline Stjerne & 257 & $43 \%$ & 0.32 & 41 & 0.88 & 800 \\
\hline Vigdis Northeast & 163 & $35 \%$ & 0.23 & 46 & 0.68 & 718 \\
\hline Skuld & 325 & $23 \%$ & 0.20 & 48 & 0.62 & 1631 \\
\hline Visund South & 581 & $45 \%$ & 0.69 & 33 & 1.42 & 837 \\
\hline Njord NW Flank & 118 & $50 \%$ & 0.41 & 38 & 1.04 & 289 \\
\hline Visund North & 104 & $24 \%$ & 0.12 & 54 & 0.42 & 837 \\
\hline Vilje South & 39 & $34 \%$ & 0.22 & 46 & 0.67 & 177 \\
\hline Hyme & 89 & $23 \%$ & 0.12 & 54 & 0.39 & 768 \\
\hline Trym & 232 & $54 \%$ & 0.46 & 37 & 1.13 & 502 \\
\hline Oselvar & 243 & $27 \%$ & 0.30 & 42 & 0.83 & 823 \\
\hline Alta & 58 & $38 \%$ & 0.26 & 44 & 0.76 & 222 \\
\hline Marulk & 422 & $41 \%$ & 0.59 & 35 & 1.30 & 719 \\
\hline Gaupe & 209 & $60 \%$ & 0.55 & 35 & 1.25 & 382 \\
\hline Jette & 29 & $16 \%$ & 0.06 & 62 & 0.22 & 467 \\
\hline Brynhild & 41 & $15 \%$ & 0.06 & 63 & 0.20 & 736 \\
\hline
\end{tabular}

Reading from left to right, the columns in this table provide the NPV after tax, the IRR, the normal NPVI, the BEP per barrel, the NPV divided by the NPV of after-tax cost (NPVCI), and finally the investment. From the table, we can rank the projects on the basis of the four different metrics and calculate aggregate investment based on the project investment figures.

Table 3.3 presents the ranking of the projects based on the IRR, while Table 3.4 presents the ranking based on the NPVI. The results demonstrate that these two metrics give the same rankings for the first 13 projects. Similarly, the six last projects from Goliat through Knarr have the same ranking. It is the projects with rankings from 14 to 21 - Visund North, Hyme Skuld, Valemon, Martin Linge, Edvard Grieg, Ekofisk South and Eldfisk II - which change their order somewhat between these two metrics. Visund North moves down from 14 to 19, Skuld moves up from 16 to 14, Valemon from 17 to 15, Hyme down from 15 to 21 and Eldfisk II up from 21 to 20. Martin Linge, Edvard Grieg and Ekofisk South retain their 
position in the sequence but move up from 18th, 19th and 20th to 16th, 17th and 18th respectively. Where the capital constraint is greater than about USD 20 billion (on a 100 per cent ownership basis), some difference will be found between the projects chosen on the basis of these two metrics. However, it might be concluded that the overall project groupings are the same for the two metrics. In other words, their classifications into best (first 13 projects), lower middle (14-21) and worst (six) are the same.

Table 3.3 Ranking based on the IRR

NPV after tax IRR NPV index USD/bbl NPV/NPV Mill. 2015 USD Aggregate Inv.

\begin{tabular}{|c|c|c|c|c|c|c|c|}
\hline & & & & & Cost & & \\
\hline Gaupe & 209 & $60 \%$ & 0.55 & 35 & 1.25 & 382 & 382 \\
\hline Trym & 232 & $54 \%$ & 0.46 & 37 & 1.13 & 502 & 884 \\
\hline Njord NW Flank & 118 & $50 \%$ & 0.41 & 38 & 1.04 & 289 & 1173 \\
\hline Visund South & 581 & $45 \%$ & 0.69 & 33 & 1.42 & 837 & 2010 \\
\hline Stjerne & 257 & $43 \%$ & 0.32 & 41 & 0.88 & 800 & 2810 \\
\hline Marulk & 422 & $41 \%$ & 0.59 & 35 & 1.30 & 719 & 3529 \\
\hline Alta & 58 & $38 \%$ & 0.26 & 44 & 0.76 & 222 & 3751 \\
\hline Vega + Vega sør & 786 & $36 \%$ & 0.47 & 37 & 1.14 & 1658 & 5409 \\
\hline Vigdis Northeast & 163 & $35 \%$ & 0.23 & 46 & 0.68 & 718 & 6126 \\
\hline Vilje South & 39 & $34 \%$ & 0.22 & 46 & 0.67 & 177 & 6303 \\
\hline Gjøa & 1645 & $28 \%$ & 0.31 & 42 & 0.85 & 5374 & 11678 \\
\hline Oselvar & 243 & $27 \%$ & 0.30 & 42 & 0.83 & 823 & 12500 \\
\hline Skarv & 1849 & $24 \%$ & 0.24 & 45 & 0.72 & 7579 & 20079 \\
\hline Visund North & 104 & $24 \%$ & 0.12 & 54 & 0.42 & 837 & 20916 \\
\hline Hyme & 89 & $23 \%$ & 0.12 & 54 & 0.39 & 768 & 21684 \\
\hline Skuld & 325 & $23 \%$ & 0.20 & 48 & 0.62 & 1631 & 23315 \\
\hline Valemon & 766 & $20 \%$ & 0.18 & 49 & 0.56 & 4319 & 27634 \\
\hline Martin Linge & 683 & $20 \%$ & 0.17 & 50 & 0.53 & 4120 & 31754 \\
\hline Edvard Grieg & 629 & $19 \%$ & 0.16 & 50 & 0.52 & 3890 & 35644 \\
\hline Ekofisk South & 588 & $18 \%$ & 0.13 & 53 & 0.45 & 4377 & 40021 \\
\hline Eldfisk II & 735 & $17 \%$ & 0.12 & 54 & 0.41 & 6089 & 46110 \\
\hline Goliat & 683 & $16 \%$ & 0.11 & 55 & 0.39 & 5969 & 52079 \\
\hline Gudrun & 344 & $16 \%$ & 0.11 & 55 & 0.38 & 3049 & 55128 \\
\hline Jette & 29 & $16 \%$ & 0.06 & 62 & 0.22 & 467 & 55595 \\
\hline Brynhild & 41 & $15 \%$ & 0.06 & 63 & 0.20 & 736 & 56331 \\
\hline Yme & 131 & $12 \%$ & 0.06 & 62 & 0.21 & 2268 & 58599 \\
\hline Knarr & 83 & $11 \%$ & 0.04 & 65 & 0.16 & 1852 & 60452 \\
\hline
\end{tabular}

Provided in the appendix, Table 3.5 presents the rankings based on BEP per barrel and NPV divided by total cost. These two criteria yielded identical rankings for this portfolio. While the normal NPVI ranking and the NPV divided by total after-tax cost would also be expected to differ, they gave the same results for this portfolio. This is because the projects presented here have the same marginal tax rate and cost profile (given our simplified assumption on input). When ranking projects across countries with different tax systems and cost structures, the results might differ substantially and the better ranking would therefore be the NPV divided by the present value of after-tax cost, since this is the relevant measure for the capital exposure by the company in the project. 
The change in ranking from the NPVI to the BEP per barrel is very small here. The only difference is that Eldfisk II and Hyme change places from 20th and 21st to 21st and 20th respectively.

It is difficult to say what ranking criteria a company chooses to use, and these are most probably applied alongside extensive portfolio aggregation at the corporate level in order to examine other parameters such as results, return on average capital employed (RoACE) and future investment commitments given variations in future price scenarios. A company would find it very difficult to use metric calculations to say something about project decisions by other companies, apart from examining the project at a "group" metric level. According to the results, this can be achieved with any of the metrics.

Table 3.4 Ranking based on NPVI

\begin{tabular}{|c|c|c|c|c|c|c|c|}
\hline & $\begin{array}{c}\text { NPV after } \\
\text { tax }\end{array}$ & IRR & NPV index & USD/bbl & $\begin{array}{c}\text { NPV/NPV } \\
\text { Cost }\end{array}$ & Mill. 2015 USD & $\begin{array}{c}\text { Aggregate } \\
\text { Inv. }\end{array}$ \\
\hline Visund South & 581 & $45 \%$ & 0.69 & 33 & 1.42 & 837 & 837 \\
\hline Marulk & 422 & $41 \%$ & 0.59 & 35 & 1.30 & 719 & 1556 \\
\hline Gaupe & 209 & $60 \%$ & 0.55 & 35 & 1.25 & 382 & 1938 \\
\hline Vega + Vega sør & 786 & $36 \%$ & 0.47 & 37 & 1.14 & 1658 & 3596 \\
\hline Trym & 232 & $54 \%$ & 0.46 & 37 & 1.13 & 502 & 4098 \\
\hline Njord NW Flank & 118 & $50 \%$ & 0.41 & 38 & 1.04 & 289 & 4387 \\
\hline Stjerne & 257 & $43 \%$ & 0.32 & 41 & 0.88 & 800 & 5186 \\
\hline Gjøa & 1645 & $28 \%$ & 0.31 & 42 & 0.85 & 5374 & 10561 \\
\hline Oselvar & 243 & $27 \%$ & 0.30 & 42 & 0.83 & 823 & 11384 \\
\hline Alta & 58 & $38 \%$ & 0.26 & 44 & 0.76 & 222 & 11606 \\
\hline Skarv & 1849 & $24 \%$ & 0.24 & 45 & 0.72 & 7579 & 19184 \\
\hline Vigdis Northeast & 163 & $35 \%$ & 0.23 & 46 & 0.68 & 718 & 19902 \\
\hline Vilje South & 39 & $34 \%$ & 0.22 & 46 & 0.67 & 177 & 20079 \\
\hline Skuld & 325 & $23 \%$ & 0.20 & 48 & 0.62 & 1631 & 21710 \\
\hline Valemon & 766 & $20 \%$ & 0.18 & 49 & 0.56 & 4319 & 26029 \\
\hline Martin Linge & 683 & $20 \%$ & 0.17 & 50 & 0.53 & 4120 & 30149 \\
\hline Edvard Grieg & 629 & $19 \%$ & 0.16 & 50 & 0.52 & 3890 & 34039 \\
\hline Ekofisk South & 588 & $18 \%$ & 0.13 & 53 & 0.45 & 4377 & 38416 \\
\hline Visund North & 104 & $24 \%$ & 0.12 & 54 & 0.42 & 837 & 39253 \\
\hline Hyme & 89 & $23 \%$ & 0.12 & 54 & 0.39 & 768 & 40021 \\
\hline Eldfisk II & 735 & $17 \%$ & 0.12 & 54 & 0.41 & 6089 & 46110 \\
\hline Goliat & 683 & $16 \%$ & 0.11 & 55 & 0.39 & 5969 & 52079 \\
\hline Gudrun & 344 & $16 \%$ & 0.11 & 55 & 0.38 & 3049 & 55128 \\
\hline Jette & 29 & $16 \%$ & 0.06 & 62 & 0.22 & 467 & 55595 \\
\hline Yme & 131 & $12 \%$ & 0.06 & 62 & 0.21 & 2268 & 57863 \\
\hline Brynhild & 41 & $15 \%$ & 0.06 & 63 & 0.20 & 736 & 58599 \\
\hline Knarr & 83 & $11 \%$ & 0.04 & 65 & 0.16 & 1852 & 60452 \\
\hline
\end{tabular}




\section{Company decision behaviour with price uncertainty}

All the above metrics are used at times by oil and gas companies when evaluating projects. However, the BEP - the price where a project has a positive NPV - seems to attract particular attention when the long-term price pattern represents the major concern. That is descriptive of the current position, with a volatile oil market. On its capital market day in June 2015, Statoil made particular mention of the need for projects to have a positive NPV at USD 50 per barrel. In table 4.1, we show the NPV and IRR of the projects given a price scenario of USD 50 per barrel. In addition, we calculate the percentage where investment must be reduced for some of the projects to satisfy the BEP criterion, and we present the NPV and IRR of the projects in a USD 80 per barrel expected price scenario, given that investment reduction.

Table 4.1 Investment reduction needed and new NPV and IRR at a price of USD 80/bbl

\begin{tabular}{|c|c|c|c|c|c|}
\hline & NPV (50 USD/bbl) & IRR & $\begin{array}{c}\text { Reduced investment } \\
\text { needed for } N P V>0\end{array}$ & $\begin{array}{l}\text { NPV ( } 80 \text { USD/bbl) } \\
\text { after inv. reduction }\end{array}$ & $\begin{array}{l}\text { New } \\
\text { IRR }\end{array}$ \\
\hline Valemon & -33 & $6.3 \%$ & $-4.0 \%$ & 799 & $21.28 \%$ \\
\hline Gudrun & -121 & $3.0 \%$ & $-20.8 \%$ & 466 & $21.30 \%$ \\
\hline Ekofisk South & -127 & $4.2 \%$ & $-15.2 \%$ & 716 & $21.30 \%$ \\
\hline Eldfisk II & -218 & $3.5 \%$ & $-18.7 \%$ & 955 & $21.29 \%$ \\
\hline Yme & -153 & $-0.1 \%$ & $-35.1 \%$ & 284 & $21.31 \%$ \\
\hline Martin Linge & -55 & $5.7 \%$ & $-7.0 \%$ & 738 & $21.28 \%$ \\
\hline Edvard Grieg & -60 & $5.5 \%$ & $-8.1 \%$ & 690 & $21.29 \%$ \\
\hline Skarv & 195 & $9.3 \%$ & & & \\
\hline Knarr & -137 & $-1.0 \%$ & $-38.6 \%$ & 220 & $21.33 \%$ \\
\hline Goliat & -233 & $3.1 \%$ & $-20.4 \%$ & 917 & $21.30 \%$ \\
\hline Gjøa & 305 & $11.9 \%$ & & & \\
\hline Vega + Vega sør & 234 & $18.0 \%$ & & & \\
\hline Stjerne & 51 & $16.4 \%$ & & & \\
\hline Vigdis Northeast & 12 & $9.7 \%$ & & & \\
\hline Skuld & 6 & $7.3 \%$ & & & \\
\hline Visund South & 210 & $24.7 \%$ & & & \\
\hline Njord NW Flank & 31 & $21.8 \%$ & & & \\
\hline Visund North & -29 & $1.1 \%$ & $-18.2 \%$ & 133 & $31.44 \%$ \\
\hline Vilje South & 2 & $9.2 \%$ & & & \\
\hline Hyme & -29 & $0.4 \%$ & $-20.5 \%$ & 120 & $31.64 \%$ \\
\hline Trym & 68 & $25.0 \%$ & & & \\
\hline Oselvar & 42 & $11.4 \%$ & & & \\
\hline Alta & 7 & $12.1 \%$ & & & \\
\hline Marulk & 142 & $21.5 \%$ & & & \\
\hline Gaupe & 68 & $29.8 \%$ & & & \\
\hline Jette & -31 & $-5.0 \%$ & $-35.0 \%$ & 60 & $31.83 \%$ \\
\hline Brynhild & -50 & $-5.6 \%$ & $-36.0 \%$ & 92 & $31.54 \%$ \\
\hline
\end{tabular}


As can been seen from the results in table 4.1, some of the projects have a positive NPV at a price scenario of USD 50 per barrel. For the projects which need an investment reduction the range is from only four per cent for Valemon to as much as 38.6 per cent for Knarr. Given this investment reduction, NPVs and IRRs in a USD 80 per barrel price scenario improve dramatically. Real rates of return reach 21 per cent for many of the projects and even 31 per cent for small projects with short production period.

\section{Conclusion}

We have examined the project ranking generated following metrics used for capital rationing in the international oil industry: internal rate of return, net present value index and breakeven price. In addition, we have tested the ranking of a new metric proposed in this article: the complete net present value index. The findings of the metrics analysis are that the overall grouping of the projects is the same with all four metrics. The highest ranked projects remain unchanged, as does the group of worst projects. It is the lower middle projects where the individual rankings differ somewhat between the ones based on the IRR and the other three ranking criteria. The great similarity in ranking results between the three metrics of BEP, NPVI and NPV/total after-tax cost generally reflects the relative profitability of the projects. The similarity in ranking results is further strengthened here by the fact that the projects are subject to the same fiscal regime, as well as the simplified assumptions made on field investment and production profiles. Comparing projects in different countries is likely to generate a different ranking due to the fact that different tax systems carry the companies' Capex to a different extent. We believe that our proposed metric, the complete net present value index, will generate more consistent rankings in this context. This is a topic for future research.

Management and professionals in the oil and gas sector, as well as industry analysts, seem to be very concerned about what supplementary criteria other companies are applying in their decision-making. Our findings indicate that they can be more relaxed about the criteria used, since different ones provide very similar rankings. A company would be ill advised to use project metrics to examine the likelihood of decisions to sanction projects in licences with multiple licensees, other than to say something about overall grouping. Any of the metrics will suffice for that purpose. 
It is difficult to say what ranking criteria oil companies actually use, and these are most probably applied alongside extensive portfolio aggregation at the corporate level in order to examine other parameters such as results, return on average capital employed (RoACE) and future investment commitments given variations in future price scenarios.

\section{References}

Bjerksund, P. and S. Ekern 1990, "Managing Investment Opportunities under Price Uncertainty: From "Last Chance" to "Wait and See" Strategies", Financial Management, vol 19, no 3, pp 65-83.

Brealey, R. A., Myers, S. C. and F. Allen 2011. Principles of Corporate Finance, ninth edition, McGraw-Hill.

Copeland, T. E. and Weston, J. F. 2005. Financial Theory and Corporate Policy, third edition, Addison-Wesley.

Emhjellen, M., Hausken, K., and P. Osmundsen (2006), "The Choice of Strategic Core - Impact of Financial Volume", International Journal of Global Energy Issues, vol 26, no 1/2, pp 136-157.

Gjesdal, F. and T. Johnsen (1999), Kravsetting, lønnsomhetsmåling og verdivurdering, Cappelen Akademiske Forlag, Oslo.

Ingersoll, J. E. Jr. and Ross, S. A. 1992. "Waiting to Invest: Investment and Uncertainty”. The Journal of Business, vol 65, no 1, pp 1-29

Jovanovic, Petar. 1999. “Application of sensitivity analysis in investment project evaluation under uncertainty and risk". International Journal of Project Management, vol 17, issue 4, pp 217-222.

Kind, H.J., Tveterås, R., and P. Osmundsen (2005), "Critical Factors in Transnational Oil Companies Localisation Decisions - Clusters and Portfolio Optimisation", in Glomsrød, S. and P. Osmundsen, eds., Petroleum Industry Regulation within Stable States. Recent Economic Analysis of Incentives in Petroleum Production and Wealth Management, Ashgate Studies in Environmental and Natural Resource Economics, Ashgate Publishers.

Lintner, J. 1965. "Security Prices, Risk and Maximal Gains from Diversification", Journal of Finance, vol 20, pp 587-615. 
Mossin, J. 1966. "Equilibrium in a Capital Asset Market”, Econometrica, vol 34, pp 768-83.

Myers, S. 1974. "Interactions of corporate financing and investment decisions-implications for capital budgeting". Journal of Finance, vol 29, issue 1, pp 1-25.

Osmundsen, P., Emhjellen. M., and M. Halleraker 2006, “Transnational Oil Companies' Investment Allocation Decisions", in Jerome Davis, ed 2006, The Changing World of Oil. An Analysis of Corporate Change and Adaptation, Ashgate Publishers, ISBN 07546-4178-3.

Osmundsen, P., Emhjellen, M., Johnsen, T., Kemp, A. and C. Riis (2015), "Petroleum taxation contingent on counter-factual investment behavior", Energy Journal 36, 1-20.

Sharpe, W. 1964. "Capital Asset Prices: A Theory of Capital Market Equilibrium under Conditions of Risk", Journal of Finance, vol 19, pp 425-442.

\section{APPENDIX}

Table 3.5 Ranking based on breakeven USD/arrel and NPV/NPV of cost (equal)

\begin{tabular}{|c|c|c|c|c|c|c|c|}
\hline & NPV after tax & IRR & NPV index & USD/bbl & $\begin{array}{c}\text { NPV/NPV } \\
\text { Cost }\end{array}$ & Mill. 2015 USD & Aggregate Inv. \\
\hline Visund South & 581 & $45 \%$ & 0.69 & 33 & 1.42 & 837 & 837 \\
\hline Marulk & 422 & $41 \%$ & 0.59 & 35 & 1.30 & 719 & 1556 \\
\hline Gaupe & 209 & $60 \%$ & 0.55 & 35 & 1.25 & 382 & 1938 \\
\hline Vega + Vega sør & 786 & $36 \%$ & 0.47 & 37 & 1.14 & 1658 & 3596 \\
\hline Trym & 232 & $54 \%$ & 0.46 & 37 & 1.13 & 502 & 4098 \\
\hline Njord NW Flank & 118 & $50 \%$ & 0.41 & 38 & 1.04 & 289 & 4387 \\
\hline Stjerne & 257 & $43 \%$ & 0.32 & 41 & 0.88 & 800 & 5186 \\
\hline Gjøa & 1645 & $28 \%$ & 0.31 & 42 & 0.85 & 5374 & 10561 \\
\hline Oselvar & 243 & $27 \%$ & 0.30 & 42 & 0.83 & 823 & 11384 \\
\hline Alta & 58 & $38 \%$ & 0.26 & 44 & 0.76 & 222 & 11606 \\
\hline Skarv & 1849 & $24 \%$ & 0.24 & 45 & 0.72 & 7579 & 19184 \\
\hline Vigdis Northeast & 163 & $35 \%$ & 0.23 & 46 & 0.68 & 718 & 19902 \\
\hline Vilje South & 39 & $34 \%$ & 0.22 & 46 & 0.67 & 177 & 20079 \\
\hline Skuld & 325 & $23 \%$ & 0.20 & 48 & 0.62 & 1631 & 21710 \\
\hline Valemon & 766 & $20 \%$ & 0.18 & 49 & 0.56 & 4319 & 26029 \\
\hline Martin Linge & 683 & $20 \%$ & 0.17 & 50 & 0.53 & 4120 & 30149 \\
\hline Edvard Grieg & 629 & $19 \%$ & 0.16 & 50 & 0.52 & 3890 & 34039 \\
\hline Ekofisk South & 588 & $18 \%$ & 0.13 & 53 & 0.45 & 4377 & 38416 \\
\hline Visund North & 104 & $24 \%$ & 0.12 & 54 & 0.42 & 837 & 39253 \\
\hline Eldfisk II & 735 & $17 \%$ & 0.12 & 54 & 0.41 & 6089 & 45342 \\
\hline Hyme & 89 & $23 \%$ & 0.12 & 54 & 0.39 & 768 & 46110 \\
\hline Goliat & 683 & $16 \%$ & 0.11 & 55 & 0.39 & 5969 & 52079 \\
\hline Gudrun & 344 & $16 \%$ & 0.11 & 55 & 0.38 & 3049 & 55128 \\
\hline Jette & 29 & $16 \%$ & 0.06 & 62 & 0.22 & 467 & 55595 \\
\hline Yme & 131 & $12 \%$ & 0.06 & 62 & 0.21 & 2268 & 57863 \\
\hline Brynhild & 41 & $15 \%$ & 0.06 & 63 & 0.20 & 736 & 58599 \\
\hline Knarr & 83 & $11 \%$ & 0.04 & 65 & 0.16 & 1852 & 60452 \\
\hline
\end{tabular}

